\title{
Identidad, política y etnicidad. La trayectoria militante de Marcos Osatinsky, fundador de las Fuerzas Armadas Revolucionarias (Argentina)*
}

\author{
Identity, politics and ethnicity. The militant career of Marcos Osatinsky, \\ founder of the Revolutionary Armed Forces (Argentina)
}

\author{
Mora GonZÁLEZ CANOSA \\ Emmanuel KAHAN \\ Universidad Nacional de La Plata
}

\begin{abstract}
RESUMEN
La trayectoria de Marcos Osatinsky, nacido en la provincia de Tucumán en 1933 y asesinado en 1975, se asemeja a una mirilla desde la cual es posible observar el mundo de las izquierdas y el peronismo durante las décadas de 1960 y 1970 en Argentina. Dirigente del Partido Comunista, se apartó para incorporarse al Ejército de Liberación Nacional formado por Ernesto Che Guevara, luego fue uno de los fundadores de las Fuerzas Armadas Revolucionarias, integró la conducción nacional de Montoneros y finalmente fue asesinado por fuerzas de represión paraestatal.

Este artículo se propone problematizar los vínculos entre judaísmo, izquierdas y peronismo en la Argentina del período a partir la trayectoria política de este emblemático militante. Para ello, primero caracterizamos las tensiones entre la cuestión judía y los programas de distintos sectores de las izquierdas y el peronismo, inscribiendo el derrotero de Osatinsky en el universo de alternativas disponibles para un amplio espectro de jóvenes de origen judío que se embarcaron en proyectos políticos de carácter emancipatorio en el país. Luego, reconstruimos su itinerario militante y, finalmente, problematizamos los modos en que fue re-judaizado por diversos actores en distintos contextos históricos.

El artículo se basa en entrevistas orales, bibliografía académica y testimonial, prensa del período y documentación producida por un amplio conjunto de organizaciones políticas.
\end{abstract}

\section{Palabras Clave:}

Identidad; etnicidad; judaísmo; peronismo; izquierdas.

\begin{abstract}
The life of Marcos Osatinsky, born in the province of Tucumán in 1933 and assassinated in 1975, provides a keyhole through which to observe the world of the left and Peronism during the 1960s and 1970s in Argentina: leader of the Communist Party, he left to join the National Liberation Army formed by Ernesto "Che" Guevara, later becoming one of the founders of the Revolutionary Armed Forces, and joining the national leadership of Montoneros before finally being assassinated by state-sanctioned repression forces.

This article aims to problematize the links between Judaism, the left, and Peronism in Argentina at the time through the political trajectory of this emblematic militant. To do so, we first characterize the tensions between the Jewish question and the programs of the various sectors of the left and Peronism, inscribing the course taken by Osatinsky within the universe of the alternatives available for the wide range of young people of Jewish origin who embarked on political projects of an emancipatory nature in the country. Then, we reconstruct his militant path and, finally, we problematize the ways in which Osatinsky was re-Judaized by various actors in different historical contexts.

The article is based on oral interviews, academic and testimonial literature, the press of the time, and documentation produced by a wide range of political organizations.
\end{abstract}

\section{KEYWORDS}

Identity; ethnicity; judaism; peronism; left.

Artículo recibido el 22-10-2020 y admitido a publicación el 26-4-2021. 
La trayectoria de Marcos Osatinsky, nacido en la provincia de Tucumán en 1933 y asesinado en 1975, se asemeja a una mirilla desde la cual es posible observar el mundo de las izquierdas y el peronismo durante las convulsionadas décadas 1960 y 1970 en Argentina. Dirigente del Partido Comunista (PC), se apartó con la idea de incorporarse al Ejército de Liberación Nacional (ELN) formado por Ernesto Che Guevara, luego fue uno de los fundadores de las Fuerzas Armadas Revolucionarias (FAR) y finalmente integró la conducción nacional de Montoneros ${ }^{1}$. Ese itinerario condensa varios de los temas que surcaron las trayectorias de numerosos jóvenes argentinos que, en aquel período, radicalizaron su militancia política ${ }^{2}$ : las rupturas al interior del mundo de las izquierdas, la legitimación de la lucha armada como forma de intervención política, la cuestión peronista y la persecución y aniquilamiento por parte de grupos paraestatales.

Estos temas estuvieron cruzados por las disyuntivas, recelos y distanciamientos de muchos jóvenes de origen familiar judío -especialmente numerosos en el caso de las FAR- que, como intentará mostrar este trabajo, si bien no solían reivindicar esa procedencia como dimensión significativa en la construcción de sus identidades culturales y/o políticas, sí fueron percibidos como tales tanto por compañeros de ruta como por sus adversarios.

*. Dedicamos este escrito a la memoria de Sara Solarz de Osatinsky, militante política durante los años sesenta y setenta en Argentina e incansable luchadora por los derechos humanos después. Sara, cuyo testimonio fue central para este artículo, murió el 23 de noviembre de 2020 en Ginebra, Suiza, la tierra de su exilio.

1. El método biográfico constituye una perspectiva metodológica y conceptual al interior de las ciencias sociales que se ha materializado a través del estudio de historias y relatos de vida, así como de trayectorias individuales situadas en diversos marcos sociales -profesionales, educativos, militantes, estatales, etc. Esta perspectiva permite identificar, a través de documentos de diverso orden, momentos y puntos de inflexión en la vida de individuos o grupos sociales, que siempre deben comprenderse en el contexto en que dichas trayectorias suceden. Como sostiene Francisco LONGA, a diferencia de las historias de vida -en que se incluyen dimensiones y documentos plurales como testimonios de allegados, relatos familiares, historias clínicas, etc.-, las trayectorias no se preocupan por la totalidad de la experiencia de un sujeto, sino que la centralidad radica en distinguir el paso de un espacio de socialización a otro en virtud de una especificidad temática estudiada. Desde este modo "el análisis de las trayectorias de los sujetos nos permite entender los diferentes tipos de desplazamientos desde geográficos, hasta profesionales, escolares y/o políticos" ("Trayectorias e historias de vida: perspectivas metodológicas para el estudio de las biografías militantes", en VI Jornadas de Sociología de la UNLP, Universidad Nacional de La Plata, (2010), disponible en http://www.memoria.fahce.unlp.edu.ar/trab_eventos/ev.5100/ev.5100.pdf; consultado en 15-6-2020).

2. En Argentina, como en muchos lugares del mundo, el proceso de radicalización política al que aludimos estuvo atravesado por la cuestión juvenil y la identificación generacional. Como es sabido, tanto el concepto de juventud como el de generación tienen una larga tradición en las ciencias sociales (entre muchos otros, Karl MANNHEIM, "El problema de las generaciones", Revista Española de Investigaciones Sociológicas, 62 (1993); Mario MARGULIS y Marcelo URResti, La juventud es más que una palabra, Buenos Aires, Biblos 1996; Pierre Bourdieu, “La 'juventud' no es más que una palabra”, en Sociología de la Juventud, México, Grijalbo, 2002. Aquí basta enfatizar que ambos remiten a construcciones que exceden la edad biológica y se articulan social y culturalmente en función de diversas variables que incluyen la cuestión etaria, pero también la clase social, el género o la etnia. También del momento histórico en que se socializa y desarrolla cierto grupo etario, lo cual contribuye a gestar formas de percibir y apreciar, experiencias y memorias comunes (MARGULIS y URRESTI, La juventud es más..., p. 3) o, como diría Raymond WiLliams, una estructura de sentimiento compartida, cierto estado de ánimo generalizado, modos de vivir y sentir en común que, en el período que nos ocupa, estuvieron atravesados por transformaciones culturales y políticas de enorme pregnancia (Marxismo y literatura, Barcelona, Península, 1980, pp. 150-158). 
Siguiendo esas claves, inscribimos el derrotero de Osatinsky en el universo de alternativas disponibles para un amplio espectro de jóvenes de origen judío que se embarcaron en distintos proyectos políticos de carácter emancipatorio en el país. En efecto, muchos de quienes se sintieron interpelados por los tópicos que enunciamos anteriormente fueron, a su vez, parte de una generación de jóvenes integrados y socializados en contextos nacionales, provinciales y locales que complejizaron, actualizaron y/o problematizaron las tramas que los ligaban con la impronta judía propia de sus mundos sociales de pertenencia. En este sentido, y como abordaremos en el primer apartado del presente artículo, los debates y tensiones en torno a la identificación con lo judío, el sionismo, Israel y el conflicto palestino constituyeron parte del andamiaje de una época en la que numerosos jóvenes judíos, como Osatinsky y muchos de sus compañeros de ruta, adscribieron a la lucha armada y persiguieron horizontes revolucionarios en el país.

Si bien no hay registros documentales que sirvan de indicio para pensar el modo en que el fundador de las FAR se relacionó con la cuestión judía, el testimonio de Sara Solarz, quien fuera su compañera y la madre de sus dos hijos -ambos desaparecidos por la última dictadura militar (1976-1983)-, permite reponer su presencia en el mundo familiar, así como la circulación de Marcos durante su infancia y adolescencia por ámbitos de sociabilidad ligados a organizaciones judías de izquierda. Con todo, también podemos adelantar que ninguno de los espacios donde él decidió militar durante su vida adulta hizo del vínculo con la identidad judía una causa central de sus reivindicaciones políticas.

En este sentido, retomamos las definiciones de Raanan Rein sobre las identidades guionadas (hyphenated Jews), entendiendo que la identidad se compone de diversas dimensiones que los sujetos ponen en juego en situaciones específicas ${ }^{3}$. Podremos advertir en este trabajo que la identidad es un constructo al que recurren los actores en función de contextos específicos y que, además, el vínculo con lo judío puede haber estado ausente de las auto-percepciones, de las formas de presentación de sí e incluso de las reivindicaciones políticas enarboladas por Marcos Osatinsky, y no obstante, su condición judía ser repuesta tanto por sus compañeros como por sus detractores. En este sentido, la dimensión étnica, nacional y/o religiosa puede ser también un recurso interpuesto por otros como un modo de deducir, sospechar e incluso denunciar los rasgos de la militancia política, el universo intelectual o las redes de socialización de militantes políticos setentistas.

El abordaje de este derrotero se sostendrá en el uso de la historia oral, así como en el relevamiento de bibliografía académica y testimonial, prensa del período y documentación producida por un amplio conjunto de organizaciones políticas. En el primer apartado caracterizamos las tensiones entre la cuestión judía y los programas de distintos sectores de las izquierdas y el peronismo. Luego, reconstruimos los momentos centrales -aquellos que permiten pensar el anudamiento entre lo individual y lo colectivo- del itinerario militante de Marcos Osatinsky. Finalmente, en el tercer apartado problematizamos los modos en que Marcos Osantinsky fue re-judaizado por un diverso conjunto de actores en distintos contextos.

3. Raanan REIN, "Nuevas aproximaciones a los conceptos de etnicidad y diáspora en América Latina: la perspectiva judía” en ídem, ¿Judíos-argentinos o argentinos-judios? Identidad, etnicidad y diáspora., Buenos Aires, Lumiere, 2011, p. 28. 


\section{Tensiones, debates y trayectorias en torno a la identidad judía durante las décadas del sesenta y el setenta}

Como sostiene el trabajo de Bea Gurwitz, las décadas de los 60 y 70 del siglo $\mathrm{XX}$ se caracterizaron por un "giro a la izquierda" de las propias instituciones de la comunidad judía en Argentina que acompañó, a grandes rasgos, las posiciones en el espacio público de amplios contingentes de actores políticos, sociales y de la cultura ${ }^{4}$. Este giro, que involucró tanto a las organizaciones sionistas como a las entidades culturales y representativas de lo judío en el país, interpeló también a quienes, desde organizaciones filiadas con las tradiciones de izquierda, como la Federación de Entidades Culturales Judías (ICUF), debieron posicionarse ante un contexto local y global dinámico.

No obstante, esta convergencia comprende una temporalidad más larga y una serie de características complejas que están lejos de poder reducirse a la identificación unívoca de los judíos con las izquierdas. Aun así, es cierto que, como señalan algunos autores, muchos inmigrantes de origen judío que arribaron al país entre fines del siglo XIX y comienzos del siglo XX constituyeron uno de los núcleos preponderantes en el desarrollo de organizaciones anarquistas, socialistas y comunistas ${ }^{5}$.

A escala global, esta dimensión fue tematizada por diversos autores ${ }^{6}$. Si bien estos no sostienen posiciones homogéneas, sus textos señalan un núcleo de preocupaciones, trayectorias y representaciones que vinculan el universo emancipatorio de las izquierdas con la experiencia marginal -de parias- que caracterizó al proceso de incorporación de los judíos en diferentes sociedades nacionales hasta, por lo menos, la segunda mitad de los 1960. Como sostienen estos trabajos, entre fines del siglo XIX y gran parte del siglo XX se podía advertir en los programas emancipatorios de las izquierdas un horizonte reparador del mundo social que constituía uno de los andamiajes culturales de una tradición judía laicizada en la Modernidad a través del proceso de emancipación de los judíos de sus ataduras religiosas.

Este vínculo entre los judíos y las izquierdas será, a su vez, uno de los vectores de los discursos nacionalistas y antisemitas que caracterizaron el derrotero del siglo XX. La idea de un complot judio universal, articulaba en un mismo discurso la figura de un enemigo particular -los judíos-, los ataques a la democracia liberal y la denuncia del peligro comunista tanto como del imperialismo. En el caso argentino, como mostrará este trabajo, sirvió incluso para sospechar, marcar y denunciar el carácter judio de militantes políticos que no se reivindicaban como tales en sus ámbitos de acción política ni enarbolaban la cuestión judía como parte de las causas por las que luchaban ${ }^{7}$.

4. Bea Gurwitz, Argentine Jews in the Age of Revolt. Betwen the New World and the Third World, Boston, Brill, 2016 (https://doi.org/10.1163/9789004329621).

5. Víctor Mirelman, En busca de una identidad, Buenos Aires, Milá/AMIA, 1988; Hernán CAMARERO, A la conquista de la clase obrera. Los comunistas y el mundo del trabajo en Argentina, 1929-1935, Buenos Aires, Siglo XXI editores, 2007, y Daniel KERSFFELD, Rusos y rojos. Judios comunistas en los tiempos del Comintern, Buenos Aires, Capital Intelectual, 2012.

6. Ezra Mendelsohn, Essential papers on Jews and the Left, Nueva York, New York University Press, 1997; Michael LöwY, Redención y utopía. El judaísmo libertario en Europa Central. Un estudio de afinidad electiva, Buenos Aires, El cielo por asalto, 1997; Enzo TRAVERSO, Los marxistas y la cuestión judia, Buenos Aires, Ediciones del Valle, 1996, y Paul MENDES, Jews and the Left, Estados Unidos/Londres, Palgrave \& Macmillan, 2014.

7. Daniel Lvovich, El antisemitismo en Argentina. Una historia moderna, Buenos Aires, Vergara, 2003. 
En el prefacio de la edición de 1966 de La liberación del judio, Albert Memmi aludía a un caso que había tenido trascendencia pública en 1962: el secuestro y tortura de Graciela Sirota por parte del Movimiento Nacionalista Tacuara ${ }^{8}$. La joven estudiante había sido tatuada con una esvástica en sus senos como corolario de la ejecución de Adolf Eichman en Jerusalén ${ }^{9}$. La referencia al caso argentino -entre otras menciones a lo que sucedía en Inglaterra, Estados Unidos y el Norte de África- ponía de manifiesto el conocimiento que se tenía entonces sobre los riesgos del normal desarrollo de la vida judía en el país. En efecto, el caso de Sirota formaba parte de una escalada antisemita que en Argentina se materializaba tanto en la virulencia de los discursos como en una serie de atentados a instituciones y de ataques y asesinatos contra diversas personas, que además de Sirota incluían los casos de Edgardo Trilnik (1960) y Raúl Alterman (1964).

Más allá de la cuestión del antisemitismo, que fue analizada por diversos autores ${ }^{10}$, otro aspecto clave de la vida judía en el país durante el período fue la resignificación de la cuestión identitaria por parte de diversos actores de la propia comunidad. Ello es perceptible al observar un conjunto de tensiones y debates públicos acaecidos durante las décadas de 1960 y 1970 en torno a la adscripción, definición e inclusión/autoexclusión de muchos jóvenes del universo de instituciones filiadas con la representación de lo judío en el espacio público comunitario y extracomunitario. En este sentido, y más allá de que hayan interpelado específicamente o no a Marcos Osatinsky y a sus compañeros de las FAR, esos debates contribuyeron de hecho a delinear el conjunto de alternativas disponibles en que se situaron, en aquel período, las opciones de los jóvenes militantes de ascendencia judía en el país y los modos en que configuraron sus proyectos políticos.

Una polémica ilustrativa de estas tensiones tuvo lugar, por ejemplo, durante 1961 en el periódico Nueva Sión. Allí Néstor Braunstein y Julio Adín mostraron posiciones encontradas en torno a un cliché de uso frecuente en la época: "Soy judío, pero no ejerzo". En su intervención, Braunstein ponía de manifiesto que el distanciamiento entre su ascendencia judía y su adscripción identitaria era fruto de consideraciones ideológicas y programáticas en torno a la necesidad de implicarse en las contiendas de la política nacional y latinoamericana, aludiendo así a la multiplicidad de dimensiones que cada sujeto podía reivindicar $-\mathrm{o}$ no- en la configuración de su identidad política ${ }^{11}$. Por su parte, Adín introducía el peso que tenía la identificación de los otros en las adscripciones identitarias. En razón de ello, el vínculo entre identidad

8. Albert Memmi, La liberación del judio, Buenos Aires, Raíces-AMIA, 1988, p. 13.

9. La recepción del caso Eichmann introdujo una serie de acusaciones, reacciones y atentados que sostenían la acusación de una doble lealtad por parte de los judíos a la nacionalidad argentina. El secuestro del criminal de guerra nazi, sucedido en mayo de 1960, por parte de la agencia de inteligencia israelí, fue el acontecimiento sobre el que se expandieron una serie de narrativas tendientes a poner en suspenso la lealtad de los judíos a la Argentina.

10. Leonardo Senkman, El antisemitismo en Argentina, Buenos Aires, EuDeBA, 1989, y Raanan REIN, Argentina, Israel y los judios, Buenos Aires, Lumiere, 2011.

11. "Cuando un joven o viejo latinoamericano de esos que lo son pero no ejercen, toma una revista o se encuentra con una publicación de la ONU donde se dice que en tal país latinoamericano, el promedio de vida por persona es de 35 años; o cuando lee que en el Chaco argentino el 100\% de las viviendas rurales está infectado por vinchucas que portan los gérmenes de la mortal enfermedad del Chagas, ¿considera su destino vinculado al de todos los latinoamericanos o cree que eso no le incumbe por el mero hecho de haber elegido desentenderse de los demás latinoamericanos? Cuando se producen hechos como la reciente invasión norteamericana a Cuba, ¿le atañen o no?" (Néstor BRAUSTEIN, "Carta de un judío que no ejerce”, Nueva Sión, 1-6-1961). 
individual e identidad judía no dependía solo de la voluntad de los jóvenes judíos sino de aquellos que, antes bien, eran detractores de la presencia judía en el país. ${ }^{12}$

La polémica entre Braustein y Adín no era una excepcionalidad argentina, sino la reconfiguración en el contexto nacional de un debate que incluía las intervenciones de intelectuales consagrados a escala global: Jean Paul Sartre, Isaac Deutscher y Albert Memmi, entre otros. Mientras que el filósofo francés sostenía que, en gran medida, la identidad judía persistía en el mundo contemporáneo debido a la insistencia de los antisemitas ${ }^{13}$, Deutscher advertía que el signo de su identificación con lo judío pasaba por la solidaridad con los perseguidos y exterminados y la lucha por la emancipación de la humanidad ${ }^{14}$. Para Memmi, finalmente, la experiencia de los judíos era la de los oprimidos y perseguidos, tanto en el pasado como en el presente, y por tanto debían luchar en torno a su propia causa ${ }^{15}$.

Los acontecimientos y debates en torno a la identidad judía resultaron de tal envergadura que una serie de intelectuales reconocidos en el ámbito público y ligados de modo diverso a la cuestión judía, tomaron posiciones. Nueva Sión, nuevamente, entrevistó a muchos de ellos en torno a los siguientes temas: "1) ¿Qué significa para Usted ser judío?; 2) ¿Qué significa para Usted Israel? y 3) ¿Qué significa para Usted la cultura judía?" ${ }^{\prime}$. La lectura de las entrevistas permite advertir un acuerdo en torno de la premisa sartreana acerca de que la identidad judía persistía por la insistencia de los inquisidores que acusaban a los judíos por todos los males de la historia. ${ }^{17}$

La polémica referida entre Braunstein y Adin introducía también, aunque aún de modo marginal, los sentidos en torno a Israel y las consideraciones cambiantes en torno al conflicto árabe-israelí de aquellos actores identificados con el ideario de las izquierdas en Argentina. Mientras que para Adín el contexto permitía hacer una valoración del sionismo como estrategia programática -la solución al problema judío era normalizar su existencia a través de la creación de un Estado Nacional que los contuviera, de modo que no fueran una minoría expuesta al antisemitismo-, para Braunstein las tensiones en torno a las adscripciones identitarias se configuraban en relación con los programas por la liberación nacional en Argentina y Latinoamérica y también por la mirada sobre el imperialismo a escala global.

12. "Cuando un joven judío - de esos que afirman ser sin ejercer- pasa junto a una pared que grita 'Mueran los judíos', ¿se incluye entre los condenados a muerte, o no ejerce? ¿Considera vinculado su destino al de todos los otros judíos cuya muerte se requiere, o cree que eso no le atañe por el mero hecho de haber elegido desentenderse de los demás judíos? Cuando oye un comentario en el que se desliza 'Judío de mierda', ¿se siente aludido, o sigue sin ejercer? Cuando hay atentados antisemitas como el del Colegio Sarmiento, ¿le atañen o no?" (IUDAIN, "Respuesta a un judío que no ejerce", Nueva Sión, 19-51961).

13. Jean Paul SARTRE, Reflexiones sobre la cuestión judía, ed. de Buenos Aires, Sur, 1946.

14. Isaac Deutscher, Los judios no judios, Buenos Aires, Kikiyón, 1969.

15. MEMMI, La liberación del judio.

16. "Encuesta a intelectuales", Nueva Sión, 16-12-1961.

17. Los entrevistados fueron José Isaacson, Bernardo Kordon, Arnoldo Liberman, Máximo Simpson, Simón Kargierman, Samuel Tarnopolsky, Boleslao Lewin, Humberto Constantini, David José Kohon y Simja Sneh. Este último sería la excepción al inscribir su definición en una perspectiva esencialista que apelaba a una "larga tradición, sufrimientos y cosas en común del pueblo": "Soy judío porque lo soy, porque no quiero y no podría de ninguna manera no serlo, porque vivo toda mi alma, todas las alegrías y todos los sufrimientos de mi pueblo en cada rincón del mundo". 
La Guerra de los Seis Días (1967) introdujo, de modo más visceral, este último asunto. Las polémicas incorporaron nuevas voces críticas hacia Israel y nuevos argumentos en los debates públicos que enfrentaron a jóvenes identificados con lo judío con otros jóvenes -algunos de origen judío, pero distanciados de tal adscripción identitaria- militantes de diversas organizaciones filiadas con la emergente Nueva Izquierda ${ }^{18}$. La consolidación de una narrativa sobre el carácter imperialista de Israel, la cuestión del sionismo como movimiento de liberación nacional y la vinculación de los movimientos juveniles sionistas con el proceso político local y su implicancia en la radicalización política constituyeron los temas más destacados en estos años. Como señala Adrián Krupnik, hacia fines de la década de los 1960 y comienzos de la de 1970, algunos grupos de jóvenes pertenecientes a movimientos juveniles judíos iniciaron un proceso de radicalización que, en algunas oportunidades, los condujo a la ruptura con las organizaciones sionistas que los habían cobijado ${ }^{19}$.

Con el retorno del peronismo al poder, el golpe militar en Chile y la Guerra de Iom Kipur -todos ellos acontecimientos de 1973-, los debates emprendidos desde los sectores progresistas judíos con las izquierdas intentarían legitimar al sionismo inscribiéndolo en el marco de las luchas sostenidas por otros movimientos de liberación nacional y apelando a las fuentes intelectuales en que abrevaban esas corrientes: Carlos Marx y Federico Engels, Franz Fanon, León Trotsky, etc. En este contexto, volvió a tener lugar un intercambio de cartas abiertas que puso en evidencia las tensiones y rupturas políticas, programáticas e identitarias entre antiguos compañeros de militancia. Por ejemplo, durante un intercambio epistolar entre militantes juveniles a raíz de la crítica efectuada por Noticias -periódico filiado con Montoneros- al accionar de Israel en el conflicto en Medio Oriente, se pusieron en evidencia los motivos que habían llevado a muchos jóvenes a abandonar la causa sionista y la auto-identificación con lo judío. Marcos Blank, un joven que aseguraba haber sido sionista antes de integrarse a la tendencia revolucionaria del peronismo, manifestaba en "Carta de un antisionista" que "las organizaciones judías agitaban en abstracto el antisemitismo para apartar a los jóvenes de la lucha concreta por la definitiva liberación de nuestra patria y nuestro pueblo". Según Blank, su propia trayectoria manifestaba que "[1]os jóvenes judíos, hoy más que nunca se dan cuenta que su definitiva liberación como judíos y como hombres pasa por asumir el camino revolucionario, tanto en Argentina, como en Latinoamérica, como en Israel" 20 .

Si bien las polémicas que reseñamos hasta aquí tuvieron lugar en publicaciones de la comunidad judía, durante la década de 1970 los alcances de estos debates

18. Eli LEDERHENDLER señala que aquella contienda resquebrajó ciertos sentidos, solidaridades y representaciones que diversos actores- sobre todo de izquierda a escala global- sostuvieron en torno a la existencia y legitimidad del Estado de Israel (The Six-Day War and the World Jewry, Bethesda, University Press of Maryland, 2000, p. 11). Para un análisis de las repercusiones en Argentina ver Maximiliano JOZAMI, "Argentine Left Parties and the 1967 Six-Day War through the Prism of Global Networks and South-South Connections", en Jahrbuch für Geschichte Lateinamerikas/ Anuario de Historia de América Latina, 56 (2019) (https://doi.org/10.15460/jbla.56.125); Emmanuel KAHAN, "Los “judíos progresistas" frente a la Guerra de los Seis Días”, en ídem, Santiago CuETO RUA y Laura RODRÍGUEZ (comps.) Memoria y violencia en el Siglo XX. Horizontes de un proyecto de investigación, Ensenada, FaHCE, 2018, y Emmanuel KAHAN, "Los sobrevivientes del Holocausto en Argentina frente a la guerra de los seis días (1967)”, Revista Historia y Memoria, 18 (2018).

19. Adrián KRUPNIK, "Cuando camino al kibutz vieron pasar al Che", en Emmanuel KAHAN et al., Consagrados y marginados, Buenos Aires, Lumiere, 2011.

20. Marcos BlanK, "Carta de un antisionista”, Nueva Sión, 9-9-1974. 
interpelaron a un público más amplio. En efecto, la revista El Descamisado, expresión de Montoneros cuando ya Osatinsky formaba parte de su conducción nacional, fue caja de resonancia de este tipo de debates en torno a la identidad judía. La polémica, registrada en la sección "Carta de Lectores", enfrentó a dos intelectuales reconocidos en el espectro de las izquierdas y el peronismo: Eduardo Goligorsky y Arnoldo Liberman. Las posiciones encontradas en torno a la obra, trayectoria y vinculación con lo judío del escritor Germán Rozenmacher ${ }^{21}$ dieron lugar a un intercambio sobre "una problemática medieval", según Goligorsky, acerca de la cuestión judía y la participación política ${ }^{22}$.

La polémica en torno a Rozenmacher permitía señalar, según Goligorsky, que "el grueso de la juventud de origen judío se viene desinteresando en nuestro país de la obsoleta temática del ghetto y de la solidaridad con la aventura colonial sionista, para insertarse en el marco más vasto de la lucha por la emancipación argentina y la liberación del Tercer Mundo". Por su parte, Liberman se servía de la polémica para advertir que su posición política e ideológica estaba próxima a quienes luchaban en el país por la "liberación nacional" pero que no por ello podía renunciar a su condición particular, la de ser judío ${ }^{23}$.

Uno de los temas destacados de esta polémica, y que permiten reconocer uno de los aspectos centrales que fraguaron las trayectorias de jóvenes militantes durante estos años -judíos y no judíos-, fue la valoración del peronismo como el movimiento con que se identificaban las mayorías populares $\mathrm{y}$, por tanto, como matriz nacional para la revolución social. Por eso, las consideraciones en torno a las dimensiones judías de la obra de Germán Rozenmacher eran denunciadas como una apropiación inadecuada y oportunista por parte de las organizaciones judías que, "por reparar la carencia de figuras identificables con una imagen actualizada, juvenil y, de ser posible, peronista [...], apelan a la más deleznable e inescrupulosa de las maniobras: tratan de apropiarse del nombre de un escritor peronista muerto, Germán Rozenmacher, a quien denigraron y hostigaron ferozmente en vida" 24 .

Estos diálogos, como se evidenció en alusiones anteriores, son ilustrativos de los modos en que el proceso de radicalización política y la peronización de las izquierdas

21. Se trata de un escritor argentino identificado con el peronismo y cuyas obras incorporan personajes con distinto grado de identificación con lo judío (Paula ANSALDO, "Réquiem para un viernes a la noche de Germán Roznemacher. Dramaturgia judeo-argentina en el teatro IFT”, en Emmanuel KAHAN et al., Hacer patria. Estudios sobre la vida judia en Argentina, Buenos Aires, Teseo, 2020). En junio de 1967 firmó una declaración pública junto a otros intelectuales -John William Cooke, Juan Carlos Coral, Héctor Agosti, Juan José Greco, Rogelio García Lupo, José Goldberg- en favor de los países árabes y condenando la actitud colonialista de Israel tras la Guerra de los Seis Días. Este posicionamiento público fue cuestionado tanto por dirigentes de las instituciones judías como por otros intelectuales que comprendieron el accionar israelí durante aquellos días, como León Rozitchner, Abelardo Castillo, Bernardo Verbitsky o Bernardo Kordon, entre otros.

22. Eduardo Goligorsky, “Carta de lectores”, El Descamisado, 13-11-1973.

23. "Porque la lucha por el cambio, la manera de insertarme en un proceso de Reconstrucción y Liberación Nacional, es solo posible a costa de no transigir en una negación que compromete mi fidelidad a mí mismo y a mis huesos: soy argentino judío y como tal deberé ser aceptado en la lucha... Soy argentino-judío y esta es mi Patria. Aquí haré mi aporte sin negar que este aporte lo hago también desde mi experiencia como judío" (en Arnoldo LIBERMAN, "Respuesta a Goligorsky", El Descamisado, 6-111973.

24. GOLIGORSKY, "Carta de lectores". 
fue permeando la militancia de jóvenes judíos durante el período ${ }^{25}$. Esta interpelación sobre sus modos de identificación y toma de distancia con lo judío, así como su rejudaización por parte de otros actores, puede apreciarse en la crónica del velatorio del estudiante Eduardo Bekerman:

\begin{abstract}
No ha sido demasiado frecuente que se pusiera en juego la relación dialéctica peronismo-judaísmo-muerte-entierro. A principios del ' 65 falleció en un accidente automovilístico un joven abogado de la Unión Obrera Textil, Saúl Hecker, muy querido entre los militantes peronistas, aunque en realidad nunca había sido muy conocido a nivel popular. En aquella época, si bien ya se había creado el Movimiento Revolucionario Peronista liderado por Gustavo Rearte y si bien el vandorismo ya suscitaba críticas, ni se soñaba siquiera con la antinomia que hoy conmueve internamente al peronismo y al país. [...] Sus familiares dispusieron velar a Hecker de acuerdo al rito judío en el velatorio de la calle Thames y Córdoba. El féretro, por supuesto, fue envuelto con la mantilla negra y el Maguen David bordado en su centro, que la AMIA envía a tal efecto. Cuando los primeros activistas fueron llegando al lugar se vio que algunos de estos -obviamente, los más recalcitrantes derechistas- salían a la calle con un gesto de disconformidad, ya que no deseaban permanecer un segundo más alli "mientras no retiren del cajón la bandera sionista".
\end{abstract}

Párrafos después, continuaba expresando la nota:

Eso fue en el '65, cuando no eran muchos los judíos que militaban en el peronismo y todavía no se habían delimitado con claridad las trincheras de izquierda y derecha que lo dividen actualmente. Nueve años después -el 24 de agosto del '74, para ser más exactos-, cuando ya las cosas están resultando más claras y se sabe bastante bien quién es quién, un joven peronista de la "tendencia" de origen judío -Eduardo Bekerman- fue asesinado en Quilmes por "Bandas fascistas", según declaró Raúl Aragón, rector del Colegio Nacional de Buenos Aires, donde Bekerman cursaba estudios. El velatorio se realizó en pleno recinto de ese tradicional establecimiento secundario de acuerdo a las normas judías y esta vez todos los asistentes (en su mayoría integrantes de Montoneros y la Tendencia) se mantuvieron frente a la "bandera sionista" con llamativo (y quizás sorprendente) respeto. Más aún: en un momento determinado solicitaron permiso para colocar una enseña montonera sobre el Maguen David. Con esa misma bandera, Bekerman fue enterrado en la Tablada, donde se vio a muchos de los presentes juramentarse en la lucha contra el fascismo, mientras hacían el conocido saludo con los dedos en "vé" 26 .

La crónica sobre el velatorio de Eduardo Bekerman condensa las vinculaciones y tensiones entre un amplio conjunto de jóvenes judíos y el proceso de radicalización política que, en Argentina, tuvo en los debates sobre el peronismo y la lucha armada uno de sus rasgos característicos. Al mismo tiempo, como sugerimos, los debates esbozados permiten ilustrar el conjunto de alternativas disponibles en que se situaron las opciones de los jóvenes militantes de ascendencia judía en el país y los diversos modos

25. Con esta expresión aludimos a los procesos por los cuales, en Argentina, durante 1960 y 1970 importantes sectores de las izquierdas, sobre todo jóvenes provenientes de la clase media ilustrada, terminaron asumiendo al peronismo como su propia identidad política. Esa "situación revisionista" respecto del fenómeno que atravesaron significativos sectores de izquierda -al decir de Carlos ALTAMIRANO- tendió a combinar el reconocimiento de la persistente identificación con el peronismo de la clase obrera, la acentuación de las potencialidades antiimperialistas y revolucionarias del movimiento, y las expectativas de hallar un "camino nacional" al socialismo, es decir, una fórmula revolucionaria que conjugara en el país socialismo, peronismo y nación (Peronismo y cultura de izquierdas, Buenos Aires, Temas, 2001). Se trata también de un proceso que, para quienes terminaron incluyéndose como parte del movimiento, conllevó fuertísimas tensiones vinculadas con su heterogeneidad social y política, así como con las complejidades y vicisitudes del liderazgo de Perón.

26. “Crónica”, Mundo Israelita, 31-8-1974.

Rubrica Contemporanea, vol. X, n. 19, 2021 
en que configuraron sus trayectorias políticas, entre ellas la de Marcos Osatinsky, que reconstruiremos a continuación.

\section{La trayectoria de Marcos Osatinsky: una mirilla al mundo de las izquierdas y el peronismo durante los convulsionados sesenta y setenta argentinos}

Nacido en 1933 en Tucumán, Marcos Osatinsky Scholssberg provenía de una familia judía. Su padre llegó de Rumania con un año de edad y se crio en la colonia Moisés Ville, en el litoral argentino. Su madre era de origen ruso. Ya asentados en Tucumán, el matrimonio y sus tres hijos vivía razonablemente bien gracias al almacén que había comprado el padre. La familia no era muy religiosa, aunque los padres de Marcos asistían al templo en fechas significativas, celebraban las fiestas y otras tradiciones judías. La política no era algo presente en la casa de la infancia.

A Sara Solarz, quien sería su compañera de vida, Marcos la conoció de chica en un club propio de la sociabilidad judía local, vinculado a la izquierda no sionista. Sara era dos años menor que él y su familia era de origen polaco, con tradición de izquierdas y había sido diezmada durante la Primera Guerra Mundial. Su abuelo materno había sido rabino, mientras que sus padres eran decididamente ateos y de simpatías comunistas; de hecho, colaboraban con la sede local del partido. Más allá de la cuestión religiosa, Sara recuerda que durante su infancia en su casa se conservaban prácticas propias de la cultura judía, como la celebración de algunas fiestas, la comida o la lengua. En efecto, su madre, dueña de una enorme biblioteca, recibía desde Buenos Aires un periódico en ídish que leía con voracidad, manteniendo la presencia del idioma en la casa. El padre de Sara, sastre de profesión, se había dedicado al comercio textil y la familia tenía un muy buen pasar económico.

A comienzos de los cincuenta, antes de casarse y tener a sus dos hijos, ambos iniciaron estudios universitarios, que dejaron tiempo después. Pese a las expectativas del padre de Sara, tampoco continuaron con el negocio de la familia Solarz, ni sostuvieron las tradiciones judías más allá de asistir a ciertas festividades en casa de los Osatinsky. Sus futuros itinerarios políticos tampoco estuvieron signados por la cuestión judía. Marcos estudió un año Medicina en Córdoba, carrera que abandonó para dedicarse de lleno a la militancia comunista en su provincia natal. Hacia fines de la década era secretario general de la Federación Juvenil Comunista (FJC) de Tucumán, y pasó luego a ser secretario de organización del Partido (PC) en la provincia. Por entonces, ambos vivían del sueldo de Sara, que trabajaba en un banco y también militaba, en su caso como responsable de la Organización de Muchachas Argentinas de la FJC (dependiente de la Unión de Mujeres Argentinas a nivel partidario) ${ }^{27}$.

El primer lustro de la década de 1960 traería nuevos aires. Por esos años, Marcos se dedicaba intensamente a la militancia partidaria: en 1963 el PC lo había enviado a la URSS para adiestrarse militarmente durante un año, previamente había viajado a Alemania del Este a realizar un curso de formación política ${ }^{28}$. Sin embargo, fue por

\section{Entrevista de la autora a Sara Solarz, 2012.}

28. Las formas en que el PC concibió la violencia dentro de su estrategia política son algo que resta indagar en profundidad. Gilbert destaca que el partido rechazaba el método guerrillero en base a una estrategia militar alternativa centrada no solo en la autodefensa, sino también en la labor clandestina dentro de las FFAA, previendo, de acuerdo al modelo ruso, que parte de sus filas debían plegarse al proceso revolucionario cuando éste se desatara. En el marco de esa estrategia se ubica el entrenamiento recibido por algunos de sus militantes en las escuelas militares de la URSS, como fue el caso de 
entonces que surgieron ciertos malestares que no tardarían en convertirse en un cuestionamiento hacia el reformismo del partido, sobre todo entre sus filas juveniles. En efecto, si a principios de los sesenta el PC era la principal fuerza de izquierda en el campo político argentino, durante esa década fue perdiendo el virtual monopolio que tenía sobre la militancia de la izquierda marxista, primero de manera soterrada y luego bajo la forma de desgranamientos y rupturas, la más importante de las cuales dará lugar al Partido Comunista Revolucionario, de orientación maoísta, ya hacia finales de la década.

Esos malestares fueron creciendo por el efecto combinado de procesos de orden nacional e internacional. Conjugaban viejos problemas, como la distancia del partido respecto de una clase obrera de persistente identidad peronista, con nuevos ejes de disidencia gestados al calor de la Revolución Cubana, las experiencias de Argelia e Indochina y el naciente conflicto chino-soviético. Básicamente, estos giraban en torno a dos grandes temas de las izquierdas que ponían en juego la línea política medular del PC argentino: el de las etapas y las vías de la revolución. Para muchos de los futuros disidentes, entre ellos Osatinsky y Solarz, Cuba devino referencia central en esos debates y en sus propios itinerarios militantes. En principio, porque la experiencia cubana parecía evidenciar la posibilidad de encarar en lo inmediato una estrategia socialista frente a un partido que dividía la revolución en fases y en el corto plazo solo planteaba la realización de tareas de tipo democrático-burgués. Además, reforzaba la discusión sobre la vía armada -particularmente guerrillera- hacia el socialismo, frente a un partido que, en línea con la política soviética, sostenía la posibilidad de acceder al socialismo por vías pacíficas ${ }^{29}$.

Tras la progresiva exteriorización de sus críticas y el intento de ganar adherentes a la idea de que el camino al socialismo pasaba por la lucha armada, en 1965 Osatinsky y Solarz fueron separados del PC. Para entonces, ya eran parte de una red de dirigentes comunistas disidentes motivados por la idea de viajar a Cuba y participar de los planes que Ernesto Che Guevara tenía para el cono sur latinoamericano. En principio se fueron del partido alrededor de quince dirigentes de la FJC, capaces de movilizar un contingente de militantes bastante numeroso. El grupo lo lideraba Alfredo Helman y, además de Osatinsky y Solarz, se destacaban las figuras de Alejo Levenson, Marcelo Kurlat, Mercedes Inés Carazo, Jorge Gadano, Alfredo Moles y Alicia Gillone, todos con

Osatinsky. Entretanto, según la percepción de Sara, su marido había viajado muy entusiasmado, aunque poco tiempo después ambos se convencerían de que el Partido utilizaba esos viajes para canalizar las inquietudes y posibles descontentos que ya podían intuirse entre sus filas (véase Isidoro GILBERT, $L a$ Fede. Alistándose para la revolución, Buenos Aires, Sudamericana, 1998 y entrevista a Solarz, 2012).

29. Sobre el PC por esos años puede verse Cristina TORTTI, 'Izquierda y 'Nueva Izquierda' en la Argentina. El caso del Partido Comunista”, Sociohistórica, 6 (1999), pp. 221-232, y Daniel CAMPIONE, "El Partido Comunista de la Argentina: Apuntes sobre su trayectoria", en Elvira CONCHEIRO, Máximo MOdONESSI y Horacio CRESPO (eds), El comunismo: otras miradas desde América Latina, México, UNAM, 2007. Sobre los grupos disidentes del partido que luego formaron las FAR, Mora GoNZÁLEZ CANOSA, "Modelo para armar. Itinerarios y ámbitos disidentes del Partido Comunista en la formación de uno de los grupos fundadores de las Fuerzas Armadas Revolucionarias (1960-1967)", Izquierdas, 12 (2012), pp. 111-142. 
considerable trayectoria en el comunismo ${ }^{30}$. Su expulsión pública a fines de 1966 en Nuestra Palabra, el semanario del partido, no hizo más que apurar su partida hacia la isla por cuestiones de seguridad ${ }^{31}$. Allí se entrenaron en tácticas de guerrilla rural en la zona de Pinar del Río, de donde retornaron en abril de 1967 con el objetivo de "conformar la columna argentina del proyecto guevarista". A su vuelta, varios se trasladaron a Perico del Carmen (Jujuy, Argentina) y exploraron la zona con la idea de crear una base de apoyo a una eventual columna guerrillera que bajaría desde Bolivia.

La muerte del Che en Bolivia, en octubre de 1967, sorprendió al grupo sin haber podido poner sus planes en marcha. Sin embargo, el itinerario guevarista de Osatinsky no culminó allí. En 1968 varios de estos militantes se integraron a la sección argentina del Ejército de Liberación Nacional (ELN), al igual que otros grupos argentinos que también se habían entrenado en Cuba. Se trató del relanzamiento del proyecto continental de Guevara, ahora bajo el mando de Inti Peredo, uno de sus antiguos combatientes bolivianos.

En lo inmediato, el ELN argentino se propuso "contribuir al desarrollo de la guerrilla en Bolivia y crear las condiciones para la instalación de un foco guerrillero en el país"32. En concreto, exploraron la zona de Tucumán, donde tejieron variadas redes políticas y montaron una mínima infraestructura previendo la futura instalación de un foco rural, y realizaron distintas acciones urbanas. Algunas de expropiación -asaltos a bancos y otras instituciones para conseguir armas y dinero-, y otras de propaganda armada, es decir, acciones de carácter netamente político cuyo objetivo central era difundir sus ideas, demostrar la eficacia del método de lucha elegido y la vulnerabilidad del enemigo. La más importante de ellas fue el incendio simultáneo de trece

30. Para la época de la ruptura, Helman integraba el Comité Central de la FJC, antes de lo cual había sido miembro de la Comisión Nacional de Organización y secretario general de la regional Mendoza, siempre en el ámbito de la juventud. Por su parte, Levenson, Kurlat y Carazo eran dirigentes destacados de la FJC en la Facultad de Exactas de la UBA, Gadano de la Facultad de Derecho, y Moles y Gillone en la de Medicina. Según Helman, para entonces el grupo contaba con unas cuarenta personas, mientras que Moles calcula que alcanzaban el centenar incluyendo a aquellos dispuestos a integrarse en una futura red de apoyo urbano a la guerrilla. Las gestiones para viajar a Cuba las hizo Helman a través de Ciro Bustos, quien aclara que las menciones a Gelman en el diario del Che (que figura entre aquellos argentinos que quería contactar para su proyecto en Bolivia), no remitían a Juan "Gelman" -el poeta, también disidente comunista y futuro dirigente de las FAR-, sino justamente a Alfredo "Helman". Quienes viajaron a la isla fueron el propio Helman, Osatinsky, Levenson, Kurlat, Moles y Gadano. Pueden verse datos sobre las trayectorias del grupo y el viaje a Cuba en entrevista de la autora a Alfredo Moles, 2010 y 2011; a Mercedes Carazo, 2012 y a Solarz, 2012; Nuestra Palabra, 8-1-1963, p. 3, y 3-3-1964, p. 7; Gregorio LEVEnSON y Ernesto JAURETCHE, Héroes. Historias de la Argentina revolucionaria, Buenos Aires, Pensamiento Nacional, 1998; Gregorio LeVEnson, De los bolcheviques a la gesta montonera, Buenos Aires, Colihue, 2000; Alfredo Helman, Il Militante, Milán, Edizione Clandestine, 2005; Ciro Bustos, El Che quiere verte, Buenos Aires, Vergara, 2007; Horacio TARCUS (dir.), Diccionario biográfico de la izquierda argentina, Buenos Aires, Emecé, 2007; Roberto BASCHETTI, La memoria de los de abajo, La Plata, De la Campana, 2007; GILBERT, La Fede, y GonZÁLEZ CANOSA, "Modelo para armar".

31. La nota de expulsión a varios miembros del grupo por sus actividades "fraccionistas" fue publicada en Nuestra Palabra, 6-12-1966, p. 4.

32. Sobre el ELN argentino puede verse su documento "Tareas para la implementación de un frente guerrillero en la Argentina" (1969), en ARCHIVO DE LA DIRECCIÓN DE INTELIGENCIA DE LA POLICÍA DE LA PROVINCIA DE BUENOS AIRES (A-DIPPBA), leg. 110; Tito DRAGO, Cara y Cruz. El Che y Fidel, Málaga, Sepha, 2007, y Mora GonZÁLEZ CANOSA "Un sendero guevarista: pervivencias y torsiones en los orígenes de las Fuerzas Armadas Revolucionarias”, Izquierdas, 15 (2013), pp. 56-83. Sobre la guerrilla de Inti Peredo en Bolivia y su proyección continental, Gustavo RoDRÍGUEZ OsTRIA, Sin tiempo para las palabras. Teoponte: la otra guerrilla guevarista en Bolivia, Cochabamba, Kipus, 2006. 
supermercados Minimax, que lograron llevar a cabo sin causar víctimas en ocasión de la visita al país de Nelson Rockefeller, en junio de 1969. Para entonces, Marcos y Sara ya se habían instalado en Buenos Aires.

Frustrada esa experiencia tras el asesinato de Peredo en septiembre de 1969, el grupo de Osatinsky se fusionó con otros dos núcleos militantes del sector argentino del ELN: el liderado por Carlos Olmedo, también formado por disidentes comunistas, entre ellos Roberto Quieto, y el dirigido por Arturo Lewinger, surgido de una escisión del Movimiento de Izquierda Revolucionaria-Praxis, orientado por Silvio Frondizi ${ }^{33}$. Quedaba así conformado el núcleo inicial de las Fuerzas Armadas Revolucionarias (FAR) que, tras sumar nuevos contingentes militantes en Córdoba y Tucumán, se presentó públicamente en julio de 1970. Lo hizo mediante un operativo de características ciertamente espectaculares: la toma de la localidad bonaerense de Garín, que fue controlada durante casi una hora. Allí, Osatinsky fue el "médico alemán" del que hablaron los testigos ante la justicia y la prensa, quien así caracterizado dirigió el operativo de copamiento de la comisaría del lugar, junto a una falsa enfermera de la Cruz Roja ${ }^{34}$. Desde entonces, Carlos Olmedo (Germán o el Jóse en la organización) fue el máximo líder de las FAR hasta su muerte, y Osatinsky (el Pelado o Lucio) y Quieto (el Negro), la segunda línea de dirección.

A partir de allí, la organización transitó desde una estrategia guevarista, de carácter continental y fuerte énfasis en la guerrilla rural, hacia otra de orden nacional basada en la lucha urbana, donde la revalorización del fenómeno peronista jugaría un rol central. Para Osatinsky, como para tantos otros militantes de la época, en esos pasajes fueron centrales algunas lecturas previas, como Rebelión en Tierra Santa, del líder sionista Menahem Beguin, relato de la resistencia armada judía contra el colonizador inglés, o el Minimanual del guerrillero urbano del brasilero Carlos Marighella. Y, por supuesto, la experiencia de lucha urbana de los Tupamaros en Uruguay ${ }^{35}$.

Además de su accionar político-militar, la organización se caracterizó por su notable impronta intelectual, que quedó plasmada en un conjunto de escritos que hasta hoy perviven en la memoria militante. Y, también, por la marcada presencia de militantes judíos en sus filas, probablemente vinculada con las redes del mundo de las

33. También formaban parte del grupo dirigido por Carlos Olmedo su hermano Osvaldo, Eusebio Maestre, Juan Pablo Maestre, Mirta Misetich, Alberto Camps, Raquel Liliana Gelín, Leonardo y Jorge Adjiman, María Angélica Sabelli, Isabel, Carlos y Liliana Goldemberg, Sergio Paz Berlín, Pilar Calveiro, Horacio y Alcira Campiglia, Claudia Urondo, María Adelaida Viñas, María Antonia Berger y Teresa Meschiatti. Más adelante, Francisco Urondo y Juan Gelman, para entonces reconocidos poetas, se incorporaron a las FAR a través de lazos familiares y políticos con integrantes de este núcleo. Entre los militantes del grupo de Arturo Lewinger estaban su hermano Jorge, Elida D’Hippolito, Eva Gruszka y Roberto Pampillo. Del grupo de Osatinsky se sumarán a las FAR Alejo Levenson (y luego también su hermano Bernardo), Kurlat, Solarz y Carazo.

34. Al respecto pueden verse los testimonios en el Sumario de la Causa Judicial abierta en relación con los hechos de Garín (A-DIPPBA, leg.222).

35. Ver Juan GASPARINI, Montoneros: final de cuentas, La Plata, De la Campana, 2008, p. 25, y TARCUS, Diccionario biográfico, p. 479. Según comenta un ex militante de las FAR, compañero de Osatinky, más allá de su "carácter derechista", de Rebelión en Tierra Santa les interesaba el énfasis en el tema de la "propaganda armada" y la necesidad de mantener el nexo político con las masas aún en contextos de conflicto armado abierto (entrevista de la autora a "Militante de FAR", 2012). De allí también que ese libro haya sido muy influyente entre los propios Tupamaros, como afirma Eduardo REY TRISTÁN en $A$ la vuelta de la esquina. La izquierda revolucionaria uruguaya, Montevideo, Fin de siglo, 2006, p. 172. 
izquierdas del que provenían sus fundadores ${ }^{36}$. En cualquier caso, la organización nunca tematizó la cuestión judía ni la convirtió, en ninguno de sus sentidos posibles, en causa de sus reivindicaciones políticas.

Esa impronta intelectual es claramente perceptible en el modo en que las FAR asumieron al peronismo como identidad política propia en 1971. Lo hicieron mediante una serie de consideraciones de orden teórico, ideológico y político que plasmaron en "Los de Garín", reportaje publicado por la revista Cristianismo y Revolución, sumamente difundido en la época. Básicamente, la operación intelectual de la FAR consistió reivindicar al peronismo como identidad política, al marxismo como método de análisis de la realidad nacional y al socialismo como objetivo final del proceso revolucionario que impulsaban. Osatinsky, que era de los más proclives a la peronización de la organización, recibió ese reportaje con entusiasmo. Por entonces estaba preso en la cárcel de Encausados de Córdoba, donde el documento causó gran repercusión. De hecho, suscitó una intensa polémica con militantes del Ejército Revolucionario del Pueblo (ERP), también detenidos allí. Se trató de uno de los debates político-intelectuales más importantes dentro del activismo armado argentino, puesto que desplegó, de modo paradigmático, las principales controversias que separaban a las organizaciones armadas de la izquierda marxista de aquellas identificadas con la izquierda peronista que, a su vez, también reivindicaban su filiación con el marxismo. En efecto, a lo largo de sus páginas se abordaron varios de los temas claves que atravesaban a las izquierdas del período, como el punto de partida del análisis para trazar una estrategia revolucionaria en Argentina (nacional/internacional); el estatuto otorgado al marxismo (teoría científica y/o identidad política); el carácter del peronismo (continuidad o ruptura en el camino al socialismo) y la forma de pensar la ideología, que en la polémica resulta indisociable tanto de los modos de considerar la experiencia obrera, como la vanguardia que debía construirse en el país ${ }^{37}$.

Paralelamente, las FAR desarrollaban una intensa actividad, llegando a crear regionales en distintos lugares del país, como Buenos Aires, Córdoba, Tucumán y luego Santa Fe y Mendoza. Durante 1971 comenzaban a plantearse cómo articular su accionar más orgánicamente con agrupaciones de activistas afines, al tiempo que también intentaban converger con las Fuerzas Armadas Peronistas, Montoneros y Descamisados en una instancia de coordinación denominada Organizaciones Armadas Peronistas. Tras la frustración de esa experiencia, finalmente se fusionaron con Montoneros.

Durante esos años, Osatinsky encabezó buena parte de las acciones de las FAR y, como mencionamos, sufrió la prisión política. Participó no solo de la toma de Garín sino también de diversas operaciones de expropiación, entre ellas el asalto al Banco Provincial de Córdoba en diciembre de 1970, donde murieron dos policías y una

36. El propio Osatinsky y Solarz, los hermanos Arturo y Jorge Lewinger, Eva Gruszka, Alejo y Bernardo Levenson, Liliana y Carlos Goldemberg, Leonardo y Jorge Adjiman, Mirta Misetich, Juan Gelman o Raquel Liliana Gelín, son algunos de los militantes de origen judío que ya hemos nombrado. Entre otros, también eran de ascendiente judío Marcelo Kurlat, Mario Lorenzo, Ivo y Adriana Koncurat, Ana Weissen, Bernardo Daniel Tolchinsky, Alfredo Elías Kohon, Víctor Klein, Marcelo Gelman o María Adelaida Viñas, por mencionar a militantes y dirigentes que fueron conocidos.

37. FAR, "Los de Garín”, Cristianismo y Revolución, 28 (1971), pp. 56-70; ERP [1971], “Crítica del ERP al Reportaje a las FAR", Militancia, 4 (1973), pp. 35-38; FAR [1971], "Nuestra respuesta elaborada por el compañero Olmedo", Militancia, 4 (1973), pp. 38-49. Pueden verse análisis sobre el debate en Esteban CAMPOS "Clases sociales, ideología y cuestión nacional en el debate entre las FAR y el PRT-ERP en Argentina", Tempo e Argumento, 16 (2015), pp. 183-204, y Mora GonzÁlez CANOsA "Marxismo, peronismo y vanguardia. La polémica entre las FAR y el ERP”, Sociohistórica, 41 (2018), pp. 1-20. 
militante de las FAR, Raquel Liliana Gelín. En ese operativo fueron detenidos -y luego duramente torturados- además de Marcos, Carlos Astudillo, Alfredo Elías Kohon y Alberto Camps ${ }^{38}$. Tiempo después, todos ellos fueron trasladados desde la cárcel de Córdoba al penal de máxima seguridad de Rawson (Chubut). Allí, Osatinsky fue elegido jefe de la espectacular fuga organizada por FAR, ERP y Montoneros en agosto de 1972, y uno de los seis guerrilleros que lograron tomar un avión comercial en el Aeropuerto de Trelew y desviarlo hacia Chile, país gobernado en ese entonces por Salvador Allende. Gracias a las gestiones del presidente, que les brindó asilo político, desde allí pudieron partir a $\mathrm{Cuba}^{39}$.

Tras reunirse con Perón en Madrid, Osatinsky regresó a la Argentina a fines de 1972, donde se reencontró con Sara Solarz (Quica o Jenny en la organización), con quien vive en la clandestinidad hasta el 25 de mayo de 1973, cuando asume la presidencia el candidato peronista Héctor Cámpora. Fueron meses de un tiempo político vertiginoso y signado por grandes dilemas. Las FAR habían apoyado la salida electoral, considerando al futuro Gobierno democrático como paso previo hacia una transformación más radical de la sociedad. Sin embargo, la nueva etapa no dejaba de plantear grandes interrogantes para este tipo de grupos: ¿cuál sería el rol de las organizaciones armadas en un futuro Gobierno peronista? ¿La lógica de los votos excluiría a partir de entonces la lógica de las armas? ¿Cómo garantizar el tránsito al socialismo a partir del Gobierno popular? En todo caso, como ya podía intuirse, la lógica de un tipo de legitimidad basada en la legalidad democrático-institucional y la de una legitimidad revolucionaria que descreía de las elecciones como medio definitivo para la toma del poder, ambas yuxtapuestas en esa apuesta, no tardarían en entrar en tensión.

Entre tanto, las FAR se esforzaban por crear o articularse con agrupaciones de activistas en distintos frentes de masas, como el sindical, el estudiantil o el barrial. En ese período, Sara militaba en diversas zonas del noroeste del Gran Buenos Aires, donde iba frecuentemente con su hijo menor, charlaba de política con las mujeres y participaba en proyectos de alfabetización de adultos. A su vez, numerosos militantes de la tendencia revolucionaria del peronismo participaban en tareas de gestión en gobernaciones afines ${ }^{40}$. Al mismo tiempo, otra tarea de primer orden para las FAR era su fusión con Montoneros, un proceso largo y complejo que fue anunciado

38. Al respecto puede verse La Nación 30-12-1970, 31-12-1970, 3-1-1971, 5-1-1971 y 7-1-1971.

39. Elías Kohon y Carlos Astudillo estuvieron entre los 19 combatientes que por fallas del operativo no pudieron subir a aquel avión, tomaron el aeropuerto, y tras ser trasladados a la Base Almirante Zar, el 22 de agosto fueron fusilados en lo que se conoce como la Masacre de Trelew. Por su parte, Alberto Camps fue uno de los tres sobrevivientes de aquellos sucesos, junto con María Antonia Berger, también de las FAR, y Ricardo René Haidar, de Montoneros.

40. Sobre la apertura electoral, la posición de la tendencia revolucionaria del peronismo y de las propias FAR puede verse Laura LENCI, "Cámpora al Gobierno, Perón al Poder. La tendencia revolucionaria del peronismo ante las elecciones del 11 de marzo de 1973”, en Alfredo PUCCIARELLI (ed.), La primacía de la política. Lanusse, Perón y la Nueva Izquierda en tiempos del GAN, Buenos Aires, Eudeba, 1999, pp. 167201 y Mora GonZÁLEZ CANOSA, “¿Democracia y/o Revolución? Las Fuerzas Armadas Revolucionarias frente a la coyuntura electoral: los comicios, la revolución y la lógica instrumental (Argentina, 19721973)”, Izquierdas 38 (2018), pp. 164-89. Sobre la participación de militantes de la tendencia en gobernaciones afines ver Alicia SERVETTO, 73/76. El gobierno peronista contra las "provincias montoneras", Buenos Aires, Siglo XXI, 2010, y Fernanda TocHO, "Lógicas políticas en tensión: la Tendencia Revolucionaria del Peronismo y su participación en el gobierno constitucional de la provincia de Buenos Aires (1973-1974)", tesis doctoral, Universidad Nacional de La Plata, 2020. 
públicamente el 12 de octubre de 1973, nada menos que el día en que Perón asumió su tercera presidencia, tras 18 años de proscripción ${ }^{41}$. Como miembro de la conducción nacional de la nueva organización unificada, Marcos Osatinsky fue protagonista de los principales avatares de Montoneros durante los años que siguieron: la escalada de violencia $^{42}$, la intensificación de la disputa con la derecha peronista, el conflicto con Perón (que en 1974 se tornará en ruptura abierta) y el pase a la clandestinidad de la organización. Todo ello sucedió en un contexto de avance de la represión estatal y paraestatal, primero con la aquiescencia del líder y, tras su muerte, de Estela Martínez de Perón, quien lo sucedió en el cargo ${ }^{43}$.

En ese contexto de escalada represiva, en agosto de 1975 Marcos Osatinsky es detenido en la capital de Córdoba junto a otros miembros de Montoneros, como recordara Rodolfo Walsh en su famosa Carta Abierta a la Junta Militar (1977), al denunciar los crímenes de las fuerzas de seguridad previos a la última dictadura militar. Secuestrado en el Departamento de Policía local, negocia el cese de la tortura a sus compañeros a cambio de la suspensión de una serie de operaciones montoneras. Sin embargo, poco después, el ERP, que desconocía las tratativas, lleva a cabo un frustrado intento de copar la central policial para liberarlos y, en represalia, todos los militantes son trasladados a la cárcel de Encausados, a excepción de Marcos, quien es brutalmente torturado y asesinado el 21 de agosto ${ }^{44}$. Para entonces, no había alcanzado a cumplir los 42 años de edad. Su asesinato es responsabilidad del capitán de Ejército Héctor Pedro Vergez, fundador del Comando Libertadores de América (grupo de represión paraestatal compuesto de militares, policías y dirigentes sindicales de intenso accionar en Córdoba), mano derecha del jefe del III Cuerpo del Ejército, General Luciano Benjamín Menéndez, y jefe del centro clandestino de detención La Perla durante la dictadura de $1976^{45}$. Fueron fuerzas a su cargo también las que secuestraron y dinamitaron el cuerpo de Marcos, interceptando el servicio fúnebre que trasladaba sus

41. Tras la fusión, Marcos Osatinsky ocupó el octavo lugar en la conducción nacional de Montoneros. A su vez, luego de ser responsable de la cuestión gremial a nivel nacional, fue jefe de la regional cordobesa, hasta que ese puesto fue ocupado por su compañero Horacio Mendizábal (oriundo de Descamisados, organización también fusionada con Montoneros).

42. Cabe recordar que, para el momento de la fusión entre FAR y Montoneros, ya habían sucedido algunos hitos claves de esa escalada, como la masacre de Ezeiza, tiroteo contra los sectores juveniles y de la izquierda del movimiento ocurrido en las cercanías del aeropuerto el 20 de junio de 1973, en ocasión del regreso de Perón al país, así como el asesinato de José Ignacio Rucci, secretario general de la Confederación General del Trabajo por parte de Montoneros, que fue leído como clara afrenta hacia el líder.

43. Un estudio sobre el avance y convergencia de la represión estatal y paraestatal, legal e ilegal durante el período 1973-1976 puede verse en Marina FrANCO, Un enemigo para la Nación. Orden interno, violencia y “subversión”, 1973-1976, Buenos Aires, FCE, 2012.

44. Véase La Opinión, 10, 22 y 26-8-1975 y también TARCUS, Diccionario biográfico y GASPARINI, Montoneros. Marcos había logrado convencer a sus captores de que él era líder de la regional cordobesa de Montoneros, cuando en realidad para entonces el verdadero jefe era Mendizábal, quien luego logró escapar de la cárcel de Encausados.

45. En su libro, VERGEZ se jacta de haber detenido a Osatinsky, aunque atribuye su muerte al ERP, en un supuesto segundo intento de liberarlo (Yo fui Vargas. El antiterrorismo por dentro, Buenos Aires, ed. del autor, 1995). Sin embargo, tal como luego relató Sara Solarz en sede judicial, fue el propio VERGEZ (quien ya la había perseguido activamente durante 1973) quien se dirigió especialmente hasta la ESMA, donde por entonces ella estaba cautiva, para contarle detalles del asesinato de su marido -adjudicándose su autoría- y de sus dos hijos. 
restos a Tucumán ${ }^{46}$. Allí aguardaba su familia, que esperaba poder darle sepultura judía en el Cementerio Israelita del lugar. El hecho fue en Barranca Yaco, junto al monolito que recuerda el asesinato de Facundo Quiroga, líder de las montoneras, ocurrido siglo y medio antes ${ }^{47}$.

Tras la muerte de Marcos, las fuerzas represivas se ensañaron con toda su familia. A Mario, su hijo mayor, que por entonces tenía 18 años y también militaba en la organización, lo asesinaron el 26 de marzo de 1976 en la localidad cordobesa de La Serranita. A José, el más pequeño, de solo 15 años, la policía provincial lo mató a balazos en julio de ese mismo año. Por su parte, Sara fue secuestrada en mayo de 1977 en Buenos Aires y trasladada a la Escuela de Mecánica de la Armada (ESMA), donde estuvo detenida-desaparecida hasta 1979. Luego de fingir colaboración y ser liberada, en octubre de ese mismo año Sara denunció junto con Alicia Milia de Pirles y Ana María Martí los crímenes de la dictadura ante la Asamblea Nacional francesa. Conocido como el testimonio de París, las tres sobrevivientes describieron allí -en pleno auge de la dictadura- el funcionamiento de la ESMA, los vuelos de la muerte y la apropiación de bebés. Desde entonces y hasta la actualidad, Sara vive en Suiza y ha sido una activa testigo en distintos juicios por los delitos de lesa humanidad cometidos en Argentina, y pionera, además, en la denuncia de la violencia sexual ejercida contra las detenidasdesaparecidas en los centros clandestinos de detención.

\section{La mirada de los otros: re-judaización de las militancias políticas nacionales}

Si bien, como analizamos en el apartado anterior, la condición judía de Marcos Osatinsky no fue tematizada por él de modo público ni por las organizaciones políticas de las que formó parte, sí constituyó un horizonte de identificación por un amplio universo de actores en contextos históricos diversos. En este sentido, además de reconocer las características de las identidades guionadas, trayectorias como la de Osatinsky permiten considerar a las identidades como un constructo en el que operan no solo las voluntades de los sujetos sino, también, las representaciones esgrimidas por otros. No se trata este último aspecto de un rasgo marginal; por el contrario, puede identificarse en qué medida esas representaciones se materializan en prácticas políticas, simbólicas y culturales concretas. Este apartado se propone problematizar algunas

46. Según documentos desclasificados del NATIONAL SECURITY ARCHIVE, los funcionarios norteamericanos se enteraron de inmediato que Osatinsky había sido torturado y asesinado por las fuerzas de seguridad argentinas, así como de que mintieron sobre las circunstancias de su muerte y se deshicieron del cuerpo para que no pudiera realizarse una autopsia. "The purpose of stealing his body was to prevent the boy from being subjected to an autopsy, which would have clearly shown that he had been tortured", reportó por entonces el agente del FBI Robert S. Scherrer. "It is doubtful that OSATINSKY's body will ever turn up", concluyó ("Recent Death of Montonero leader Marcos Osatinsky in Cordoba," Secret, August 26, 1975", en https://assets.documentcloud.org/documents/5817663/National-Security-ArchiveDoc-02-FBI-Cable.pdf, consultado el 15-9-2020).

47. Las derivas del asesinato de Osatinsky no terminaron allí y tuvieron más consecuencias trágicas al interior de Montoneros. Días después del hecho, la organización acusó a uno de sus militantes, Fernando Haymal, de haber brindado bajo tortura información clave en la detención de Marcos y sus compañeros. Declarado culpable por los cargos de traición y delación tras ser sometido a un juicio revolucionario, fue asesinado en Córdoba. El ajusticiamiento fue difundido en Evita Montonera 8 (octubre de 1975). Para una problematización del tema de la justicia revolucionaria montonera y las ejecuciones internas puede verse Laura LENCI, "Justicia, política y violencia. Un análisis de los cuerpos normativos montoneros 1972-1975", en Jornada de Partidos Armados en la Argentina de los Años Setenta, Buenos Aires, Universidad Nacional de San Martín, 2008. 
expresiones cuya pretensión de re-judaizar a Marcos Osatinsky pueden ser ilustrativas de los efectos, disputas, apropiaciones y sentidos cambiantes que adquiere la identificación judía de una trayectoria militante.

En primer lugar, podemos advertir que, aun cuando Marcos no haya tematizado la cuestión judía como causa de sus reivindicaciones políticas, la misma formó parte del universo afectivo y familiar. En efecto, como destaca Sara Solarz al relatar la niñez y adolescencia de ambos, o como puede verse a través del tránsito frustrado del féretro de Osatinsky hacia el cementerio de Tucumán, la presencia de lo judío constituyó parte del ambiente familiar. Como en los casos de Saúl Hecker y Eduardo Bekerman que abordamos en el primer apartado, ese registro es revelador de las rupturas y tensiones que suscitó en ámbitos familiares el proceso de integración y socialización de los jóvenes en ámbitos de la cultura y la política nacional. Lo mismo puede pensarse en relación con la trayectoria de los Blaustein retratada en el film Hacer patria, que problematiza los jalones y desgarramientos de una historia familiar cuyo primer registro en Argentina es la llegada de inmigrantes judíos religiosos a comienzos del siglo XX y el posterior devenir de un ciclo de rupturas con la identificación judía cuando uno de los hijos se afilia al Partido Comunista y la generación posterior inicia su militancia política en el peronismo revolucionario (entre ellos el propio David Blaustein, cercano justamente a las FAR). Si bien lo judio no conforma un eje vertebrador de las prácticas políticas de los actores, tiene una enorme pregnancia en el universo filial y afectivo ${ }^{48}$.

La condición judía en el derrotero de Marcos Osatinsky, como la de tantos otros jóvenes que se incorporaron a la militancia revolucionaria entre las décadas de 19601970, no pasó desapercibida para sus coetáneos; por el contrario, fue repuesta tanto por quienes fueron aliados en la militancia política como por sus detractores. Ello se advierte, por ejemplo, en los cánticos de la época, como señala Tcach en su clásico trabajo sobre las consignas políticas utilizadas durante los años 1970. En efecto, uno de los cánticos con que militantes de Montoneros desacreditaban a sus compañeros de las FAR ironizaba: “¿Dónde están los faroles? / ¿Los faroles dónde están? / En la Sinagoga / Leyendo a Carlos Marx". Como sostiene Tcach:

\footnotetext{
El término "faroles" aludía de modo irónico a los militantes de las FAR. Esta consigna es previa a la fusión con Montoneros y era usada por éstos para indicar que sus principales competidores no eran peronistas plenos sino judios marxistas ${ }^{49}$. Los datos de la realidad que inspiraban la "chicana" se relacionaban con: A) Sus miembros fundadores provenían de una escisión del Partido Comunista que, tempranamente, había entrado en contacto con el "Che" Guevara. Su aspiración primigenia era ser el referente central de Ernesto Guevara en Argentina. B) Parte de los miembros fundadores de las FAR eran judíos:
}

48. David Blaustein, Hacer patria, Buenos Aires, 2007.

49. Subrayamos en este punto lo sugestivo de la expresión que el autor recoge como voz de los actores para explicar el cántico: la plenitud del peronismo como una esencia que, en su pureza, excluiría cualquier hibridación, tanto con el marxismo como con el judaísmo. 
Marcos Osatinsky (ex-secretario general del PC en Tucumán durante varios años), Raquel Gelin, Alejo Levenson, entre otros ${ }^{50}$.

En este sentido, si bien como hemos mostrado muchos jóvenes judíos se sintieron interpelados por el proceso de peronización de las izquierdas, su incorporación a las organizaciones peronistas revolucionarias no estuvo librada de tensiones. No obstante, aun cuando las representaciones tendieran a colocar lo judio como un cuerpo extraño, las burlas de los cánticos distaban de las narrativas que, por esos mismos años, sostenían las organizaciones de la derecha nacionalista y, también, peronista en torno de los judíos.

Imagen 1: Caricatura en la revista El Caudillo de septiembre de 1973

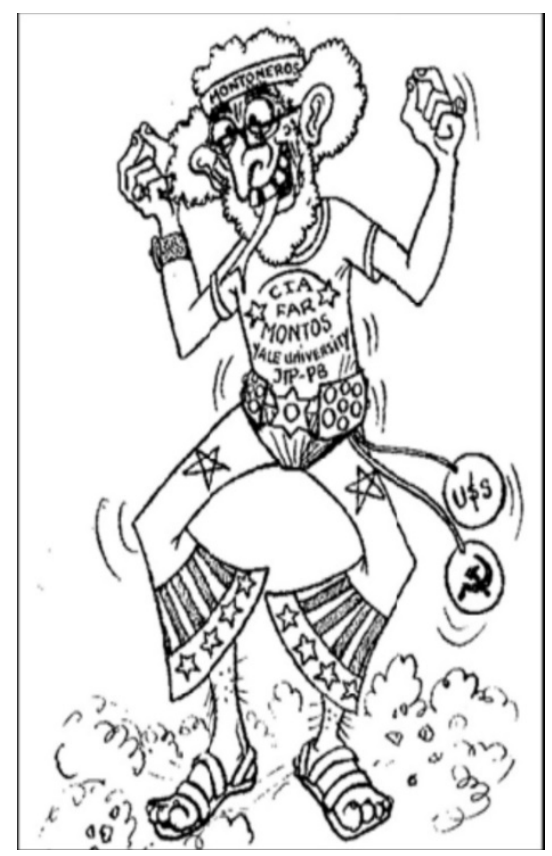

La imagen, expresiva de sectores de la ultraderecha peronista, resulta ilustrativa de los sentidos asignados a la militancia en las organizaciones peronistas de izquierda. La caricaturización del judío con una serie de estereotipos consagrados del antisemitismo vernáculo -la homologación con la CIA, la Universidad de Yale como símbolo de la intelectualidad, las referencias tanto a la moneda estadounidense como a la URSS-, es puesta en diálogo con las organizaciones del peronismo de izquierda Montoneros, FAR, Juventud Trabajadora Peronista (JTP) y Peronismo de Base (PB)-; todo ello está reconfigurado bajo uno de los símbolos de la modernización cultural del período: la imagen del joven hippie.

50. César TCACH, “Los 70': la voz de las consignas”, Anuario IEHS, 16 (2001), p. 42. En un contexto muy distinto, Norma Arrostito, dirigente montonera, también señaló la condición judía de muchos de sus miembros como un rasgo característico de las FAR. En efecto, en la historia de Montoneros que escribió mientras estaba cautiva en la ESMA, Arrostito señaló que "Los cuadros de FAR eran provenientes fundamentalmente de la clase media intelectual, de ahí la gran cantidad de judíos que integraban sus filas" (documento publicado por Juan GASPARINI - ex montonero y compañero de cautiverio en la ESMA- en "Los papeles de Norma Arrostito en la ESMA", Perfil, 4-92020, disponible en https://www.perfil.com/noticias/politica/papeles-de-norma-arrostito-en-la-esma.phtml (consultado en 109-2020). 
Como han sostenido diversos autores, las narrativas esgrimidas por sectores nacionalistas de derecha con distinto grado de vinculación con el peronismo, hicieron del antisemitismo y la denuncia de la sinarquía una de las representaciones disponibles para señalar el peligro judio tras los programas de modernización cultural, revolución política y emancipación social. En este sentido, la incorporación de FAR -y también de Montoneros- en la caricatura era resultado de la identificación que estos sectores hacían de la participación de judíos entre sus cuadros militantes ${ }^{51}$.

Estas mecánicas de re-judaización de las trayectorias de jóvenes judíos que militaron en organizaciones de la nueva izquierda durante los años 1970 se materializó, años después, en las distintas nóminas construidas en torno a los "detenidosdesaparecidos de origen judío" durante la última dictadura militar. Las mismas constituyeron una de las estrategias desarrolladas por colectivos vinculados a la defensa de los derechos humanos entre fines de la década de 1990 y comienzos del siglo XXI, cuando la cuestión de la memoria en torno al pasado reciente comenzó a cobrar mayor legitimidad pública. Si bien en el caso de las listas de víctimas judías el objetivo fue visibilizar a escala local e internacional el rasgo antisemita de la dictadura, su elaboración no estuvo exenta de polémicas, al tiempo que el número de individuos incorporados fue creciente ${ }^{52}$.

El caso de Marcos Osatinsky, por ejemplo, fue incorporado al libro Homenaje a los Desaparecidos de la Comunidad Judía de Córdoba realizado por el Centro Unión Israelita bajo la coordinación del Rabino Marcelo Polacoff. Su nombre y el de sus hijos, Mario y José, se suman a la nómina de "detenidos-desaparecidos de origen judío". Esta re-judaización, además, conllevaba una despolitización de su trayectoria militante:

\begin{abstract}
Muchos de los jóvenes que aquí recordamos empuñaron como únicas armas sus sueños, sus utopías de tener un lugar mejor para vivir. A veces, es cierto, no eran las únicas. Estaban acompañadas de panfletos, de canciones y poemas, de reuniones a medianoche, de demostraciones, o de marchas, o de un reclamo de un boleto estudiantil diseñado en una noche con lápices ${ }^{53}$.
\end{abstract}

Sobre Marcos la descripción es, además, sucinta: "Fue visitador médico; luego entró en la organización FAR y Montoneros" "54. Por el contrario, el nombre de Marcos Osatinsky no está en la última lista de "detenidos-desaparecidos de origen judío" elaborada por el Centro de Estudios Sociales de la Delegación de Asociaciones Israelitas de la República Argentina ${ }^{55}$. Por su parte, su hijo pequeño, José, sí se

51. SenKman, El antisemitismo en Argentina; Ernesto BoHoslaVsKy, El complot patagónico, Buenos Aires, Prometeo, 2009, y Juan Luis BESOKY, "La derecha también se ríe", Tempo e Argumento, 18 (2016).

52. Emmanuel KAHAN, "Discursos y representaciones en conflicto sobre la actuación de la comunidad judía durante la última dictadura militar: análisis de los Informes sobre 'los detenidos-desaparecidos de origen judío' (1984-2007)", en ídem et al., Marginados y consagrados. Nuevos estudios sobre la vida judia en Argentina, Buenos Aires, Lumiere, 2011, pp. 171-195.

53. Marcelo Polacoff, Homenaje a los desaparecidos judios de la provincia de Córdoba, Córdoba, DAIA-filial Córdoba, 2020, p. 2.

54. Ibídem, p. 52.

55. CES-DAIA, Informe sobre detenidos-desaparecidos de origen judio, Buenos Aires, CES-DAIA, 2007. 
encuentra en el listado elaborado por la Comisión de Solidaridad con Familiares de Presos y Desaparecidos en la Argentina ${ }^{56}$.

Por otro lado, y en sentido contrario, no es poco habitual encontrar el nombre de Osatinsky en el panteón de una serie de militantes judíos que -comenzando por el anarquista Simón Radowitzky que protagonizó el asesinato del Comisario Ramón Falcón- lucharon en el país por causas emancipatorias de diverso orden. Se trata de una práctica usual desde fines del pasado siglo por parte de sectores que, reconociéndose como judíos progresistas, recuperan estas figuras como un modo de marcar distancia con las instituciones reconocidas públicamente como portadoras de la representación judía en Argentina. ${ }^{57}$ Estas reivindicaciones no se realizan en función de sedimentar el imaginario de los judíos como víctimas del antisemitismo -como en el caso de los listados sobre desaparecidos-, sino de consagrar un modo de integración al escenario político nacional basado en valores alternativos a los transmitidos por las instituciones centrales: el apoyo a Israel, las prácticas religiosas, la reproducción de sentidos de pertenencia endogámicos. Por el contario, reponen sobre todo la politicidad de los actores y tienen como función inventar una tradición que ligue las luchas por la emancipación nacional que emprendieron con la auto-adscripción a lo judío.

\section{Consideraciones finales}

A lo largo de estas páginas hemos buscado problematizar los modos en que los horizontes revolucionarios de una época interpelaron a numerosos jóvenes de origen judío en la Argentina. Para ello elegimos reconstruir un itinerario singular: la trayectoria de Marcos Osatinsky. Se trata de una biografía militante extraordinariamente rica que, como una suerte de mirilla, nos permite asomarnos a los dilemas de una época. En efecto, si pensamos en las distintas estaciones de ese itinerario político, así como en sus principales inflexiones, es posible advertir cómo se anudan allí lo individual y lo colectivo, cómo a partir de una vida podemos recorrer los grandes temas del mundo de las izquierdas y el peronismo durante los sesenta y setenta argentinos. Desde la militancia comunista y sus disidencias; pasando por la Cuba revolucionaria, el Che Guevara y el tema de la lucha armada; el pasaje desde las estrategias continentales y rurales a las nacionales y urbanas; la peronización de importantes sectores juveniles de la izquierda marxista; el fenómeno de una organización político-militar como Montoneros, hasta la experiencia de la prisión política, la tortura, y el accionar de la represión paraestatal desplegada en Argentina en las vísperas de la última dictadura militar, que además, tras el asesinato de Marcos, se ensañó con toda su familia.

En este sentido, si bien no estaba en las intenciones originales del trabajo, a lo largo de estas páginas hemos visto crecer la figura de la propia Sara Solarz, testigo clave de nuestra pesquisa. Ella fue, en principio, una militante sumamente comprometida en los distintos partidos y organizaciones por los que transitó, a lo largo de una vida política que habían decido recorrer juntos con Marcos, y luego con sus hijos. Pero, además, el itinerario de Sara posterior a su cautiverio en la ESMA, su decidida denuncia

56. CO. SO. FAM, La violación de los derechos humanos de argentinos judios bajo el régimen militar (1976-1983), Buenos Aires, Milá/AMIA, 2006.

57. Hernán Schiller, "La letra de la resistencia”, Página/12, 10-12- 2008; Ricardo Forster, "Con Bergman, Macri apela burdamente al estereotipo del amigo judío", Nueva Sión, 27-9-2011; Jorge ELBAuM, "Retomar el legado popular y progresista", Página/12, 23-9-2015. 
de los crímenes cometidos por la última dictadura militar y su compromiso con los derechos humanos, nos permite asomarnos a uno de los movimientos sociales más vitales de la Argentina democrática.

Además de reconstruir estas trayectorias militantes, las hemos inscrito -la de Marcos, Sara y tantos otros compañeros de las FAR de la misma ascendencia-, en el universo de alternativas disponibles para un amplio contingente de jóvenes de origen judío que se sintieron interpelados por diversos proyectos políticos de carácter emancipatorio en el país. Como vimos, Osatinsky se encuentra entre aquellos que no reivindicaron su ascendencia judía como dimensión significativa de sus identidades políticas, ni militaron en partidos y organizaciones que convirtieran la cuestión judía en causa de sus reivindicaciones políticas. Aun así, también es cierto que, como hemos mostrado, es posible advertir la presencia o bien la re-emergencia de la cuestión judía en momentos claves de su vida. Básicamente en aquellos en que se evidencia la pregnancia del mundo familiar de origen, ya sea durante la infancia y la adolescencia, o en el momento de su muerte, esa escena final en que sus deudos esperan el cuerpo de Marcos para darle sepultura en el cementerio judío de Tucumán.

Por último, también hemos mostrado los modos en que otros -ya no solo la familia de origen- repusieron esa condición judía que Marcos no había reivindicado, al menos, como causa de sus luchas políticas. Es decir, ese proceso de re-judaización por medio del cual, actores por cierto muy disímiles, ya en vida de Marcos, pero sobre tras su muerte, lo marcaron, denunciaron, recordaron, excluyeron o bien lo reivindicaron en virtud de aquella ascendencia. ¿En qué consistió, pues, esa condición judía a la que reenviaron a Marcos a través de esas múltiples operaciones de la memoria? Lejos de toda concepción esencialista, la respuesta no puede más que remitir a las batallas por la definición de la judeidad que cada uno de esos actores estaba librando en sus respectivos presentes. 